\title{
ESTADO, EDUCAÇÃO E DEMOCRACIA NO BRASIL: RETROCESSOS E RESISTÊNCIAS*
}

\author{
Luiz Fernandes Dourado ${ }^{1}$
}

\begin{abstract}
RESUMO: O artigo situa a relação Estado, democracia e educação no contexto atual do Brasil, pautado por políticas neoliberais, as quais são expressas por reformas e ajustes estruturais em sintonia com a expansão do capital, em detrimento das políticas sociais. Partindo da premissa de que se trata de movimento global do capital, que se efetiva com contextos e dinâmicas peculiares, analisa-se o caso emblemático brasileiro. Finaliza descortinando os retrocessos que afetam as atuais políticas sociais, sobretudo as políticas e gestão da Educação. Tendo por eixos a defesa da Constituição Federal e do Plano Nacional de Educação, sinaliza a necessidade de uma unidade de luta envolvendo a sociedade civil em prol da democracia, Estado Democrático de Direito, justiça social e de garantia de educação para todos e todas.
\end{abstract}

Palavras-chave: Constituição Federal. Democracia. Educação. Estado. Neoliberalismo. Plano Nacional de Educação.

\section{STATE, EDUCATION AND DEMOCRACY IN BRAZIL: SETBACKS AND RESISTANCES}

\begin{abstract}
The article places the relationship between State, democracy and education in the current Brazilian context, based on neoliberal policies expressed by reforms and structural adjustments in line with the expansion of capital and to the detriment of social policies. Starting from the premise that it is a global capital movement that takes place with peculiar contexts and dynamics, this article situates the emblematic Brazilian case. It is concluded by revealing the setbacks that affect current social policies, mainly the policies and management of education. With the defense of the Federal Constitution and the National Education Plan, it points out the need for a unity of struggle involving civil society on behalf of democracy, democratic state of law, social justice and the guarantee of education for all.
\end{abstract}

Keywords: Federal Constitution. Democracy. Education. State. Neoliberalism. Plano Nacional de Educação.

\footnotetext{
*Este artigo vincula-se ao projeto de pesquisa "Políticas e gestão da educação : novas formas de governança e privatização".

${ }^{1}$ Universidade Federal de Goiás - Goiânia (GO), Brasil. E-mail: luizdourado2@gmail.com DOI: 10.1590/ES0101-73302019224639
} 


\title{
ESTADO, EDUCACIÓN Y DEMOCRACIA EN BRASIL: REVESES Y RESISTENCIAS
}

\begin{abstract}
Resumen: El artículo sitúa la relación entre Estado, democracia y educación en el contexto actual de Brasil, basados en políticas neoliberales, expresadas por reformas y ajustes estructurales en sintonía con la expansión del capital, en detrimento de las políticas sociales. A partir de la premisa de que es un movimiento global del capital que se efectúa en contextos y dinámicas peculiares, encontramos el caso emblemático brasileño. Concluye revelando los reveses que afectan las políticas sociales actuales, sobre todo las políticas y la gestión de la educación. Teniendo como ejes la defensa de la Constitución Federal y el Plan Nacional de Educación, indica la necesidad de una unidad de combate que implica la sociedad civil por la democracia, el estado de derecho democrático, la justicia social y la garantía de educación para todos/as.
\end{abstract}

Palabras clave: Constitución Federal. Democracia. Educación. Estado. Neoliberalismo. Plano Nacional de Educação.

\section{Educação, Estado e democracia: algumas sinalizações}

A temática democracia, Estado ${ }^{1}$ e educação é muito instigante e faz parte da agenda brasileira, sobretudo das políticas e gestão da educação. Essa tríade tem sido objeto de lutas e movimentos diversos. Se partirmos da premissa que vivemos em um cenário de mudanças que impactam a vida social, as políticas públicas e, nesse contexto, a educação, a partir de proposições, tensionamentos e desafios em escala global, nacional, local e institucional, essa discussão ganha em escala, sobretudo num contexto de grandes retrocessos e, paradoxalmente, de resistências. Não por acaso, ao remeter a relação democracia, Estado e educação, a temática permite resgatar processos históricos, bem como situar os embates atuais expressos em retrocessos no campo das políticas públicas, decorrentes e fruto de orientaçóes hegemônicas conservadoras no âmbito das relaçôes sociais vigentes.

Nessa perspectiva, é fundamental situarmos a presença de uma agenda global transnacional, cuja proposição é cada vez mais homogeneizadora e, paradoxalmente, plural e combinada. Essa agenda é demarcada pelo ethos capitalista por meio de dinâmicas da sociedade que se intercruzam, envolvendo políticas de ajuste fiscal, privatização, minimizaçáo do papel do Estado no tocante às políticas públicas, novas formas de governança e gestão, tendo por eixo o estado avaliador, o quase mercado e, de maneira mais complexa, permeado por um intenso e desigual processo de financeirização ${ }^{2}$ em todas as arenas, inclusive na educação. 
Esse cenário de mudanças e também de crise do capitalismo - que é transnacional — tem possibilitado o aprofundamento de reformas neoliberais sob o eixo da redução do Estado nas políticas sociais e sua retomada para a expansão do capital, novos formatos e complexificação de processos de privatização, desregulamentaçáo da economia, flexibilização da legislaçáo trabalhista, novos processos de gestão, financiamento, regulação e avaliação. Enfim, vivenciamos, em escala global e com impacto nos contextos nacionais e locais, a naturalização do processo de financeirização cuja lógica, dinâmica e alavanca de poder só contribuem para a reprodução do capital ${ }^{3}$.

Esse movimento global efetivou-se em vários países, com contextos e dinâmicas peculiares, estruturados sob a ótica da expansão do capital. Segundo Mészaros (2002, p. 781), "as formas particulares de personificação do capital podem variar consideravelmente, contanto, que as formas assumidas se moldem às exigências que emanam das características definidoras essenciais do sistema”.

O caso brasileiro é emblemático e só é compreensível a partir de uma retomada histórica contextualizada, pois não se apresenta como mera expressão dos embates nacionais, a despeito das peculiaridades locais e das forças sociais que tensionam o debate, as proposiçóes e as resistências em curso no Estado brasileiro. É preciso compreender o caso brasileiro com base na dialética entre o local, o nacional e o mundial.

Entender esse cenário sob a perspectiva dessa complexa configuração histórico-social é um grande desafio para as ciências humanas e sociais e, por seu turno, para a construção de alternativas fundamentadas na totalidade geo-histórica de alcance global, das contradiçóes e tensóes que marcam a história da estrutural relação capital e trabalho e, nesta seara, os movimentos e lutas em prol do Estado Democrático de Direito e de ampliação dos direitos sociais, entre eles, a educação.

\section{A formação social brasileira: antecedentes históricos}

A história da formação social brasileira é marcada por importantes movimentos e lutas desde o processo de ocupação pelos portugueses, cuja lógica política tem sido caracterizada por continuidades, rupturas e inovaçóes (IANNI, 2004) resultantes dos desafios postos pelos movimentos sociais e desafiados pela força dos interesses externos.

Com base em uma perspectiva histórica, segundo Ianni (2004, p. 7-8), o "que temos no país, são processos fortemente marcados pelo conservadorismo e colonialismo, impulsionados pelas demandas do capital e por uma política hegemônica de alianças que se nega a democratizar o poder estatal e as relaçóes sociais". Essa lógica política, a despeito de ajustes, permaneceu até o Império. 
A República, apesar dos movimentos de setores sociais urbanos visando democratizar o poder estatal, manteve a lógica política da combinação entre os interesses da burguesia emergente e dos grupos dominantes remanescentes.

Sobre esse processo histórico e a instauração do regime republicano no Brasil, são singulares as análises de Rosemberg (2016, p. 10), sobretudo para compreendermos a inserção internacional e os paradoxos do liberalismo do país, num cenário de Estado autoritário:

As veleidades democráticas de uma República liberal representativa foram solapadas por um conluio político que limitava a participação política e condicionava a inserção na esfera da cidadania aos interesses do Estado, que se revigorava.

Ainda que tenha havido um rearranjo na elite que conduzia os negócios públicos, a elite econômica, principalmente a oligarquia cafeeira paulista, foi a principal beneficiada com o novo ajuste.

Ao mesmo tempo, a consolidação da alternativa agroexportadora, carreada pela lavoura cafeeira, dependia de um esquema que viabilizasse a substituição da mão-de-obra escrava por outra que se mostrasse igualmente compensatória sob o ponto de vista econômico. A ingerência do Estado (principalmente do governo paulista) na subvençáo da imigraçáo estrangeira, principalmente italiana, possibilitou a inundação do mercado de trabalho com excesso de braços, mantendo ao tempo a produção e o baixo nível salarial.

Cabia, portanto, às autoridades e aos interessados o controle sobre essa multidão recém-arribada, que se inseria numa ordem em que, ao menos formalmente, deveriam vigorar relaçóes pautadas no espírito de liberalismo e de equidade legal adotado pela constituição de 1891.

Finalmente esvaziado de veleidades democráticas e cidadãs, o projeto republicano que se impôs forjou o enquadramento autoritário do país na "modernidade" internacional fazia necessária a presença de um Estado autoritário, quando náo repressivo, que controlasse a mão-de-obra, as sujeitando a força de trabalho disponível (ROSEMBERG, 2016, p. 10).

Nesse cenário, “a questão nacional está sempre presente, como desafio, obsessão, impasse ou incidente" (IANNI, 2004, p. 27). Por essa razão, este autor sinaliza que, na década de 1930, questôes de grande importância foram problema- 
tizadas, a despeito dos limites oriundos do escravismo, coronelismo e clientelismo 5 . É importante situar, nesse período, proposições direcionadas à estruturação da educação brasileira, destacando, nesse processo, o manifesto dos pioneiros da educação nova, abrigando intelectuais de diversos matizes teóricos.

A dinâmica sociopolítica brasileira, como vimos, não é linear, mas pautada por um "desenvolvimento desigual e combinado" (IANNI, 2004, p. 61). Essa compreensão remete-nos a uma análise dialética do processo histórico brasileiro, ressaltando os limites da modernização conservadora ${ }^{6}$, expressa no embate entre classes sociais no país e nas lutas pela democratização do Estado, como fundamentos da constituição da formação social brasileira e de seu caráter de classe. Segundo Ianni (2004, p. 44, grifo nosso),

a história do Brasil Moderno não termina aqui. Depois de 1930, virão 1945, 1964, 1985 e outras datas, simbolizando rupturas, retrocessos, aberturas. A sociedade continuou a modificar-se, em termos sociais, econômicos, politicos e culturais. O que não significa que sempre se modificou para melhor, segundo os interesses da maioria do povo.

Esse processo produziu impactos na formação social brasileira capitalista, demarcando a constituição de uma burguesia dependente e associada, ou seja,

a burguesia brasileira, ou nacional. Ela existe e náo existe. Existe como expressáo de interesses de setores sociais ligados à indústria, agricultura, comércio e banco. [...] Essa burguesia, no entanto, não se manteve nem se mantém independente. Devido a injunçóes econômicas, tecnológicas, políticas e outras, é levada a acomodar-se e associar-se (IANNI, 2004, p. 67-68).

Essa burguesia corporativa, sem projeto político para a sociedade nacional, não tem compromisso com a democracia, com o Estado Democrático de Direito e suas decorrências. $\mathrm{Na}$ esteira de sua visão restrita de classe, tem se forjado, historicamente, por meio de processos de reformas pelo alto, pautados, em muitos casos, por golpes de Estado e diversificados movimentos autoritários, conservadores, sem efetivo compromisso sequer com a democracia liberal ${ }^{7}$. Nessa direção, o Estado no Brasil é patrimonial e, portanto, trata-se de um estado excludente e de classe, a despeito das lutas históricas em prol do Estado Democrático de Direito.

\section{Políticas públicas e as lutas pela democratização do Estado brasileiro}

A retomada histórica que fizemos da formação social brasileira evidencia os complexos limites postos à luta pela democratização do Estado brasileiro e, portanto, da agenda das políticas sociais e, consequentemente, da efetivação 
e consolidação dos direitos sociais. O processo de modernização conservadora é excludente e se consubstancia, segundo análise feita por Coutinho (1979), pela adoção da via prussiana no Brasil:

Como já foi assinalado várias vezes, as transformaçôes políticas e a modernizaçáo econômico-social no Brasil foram sempre efetuadas no quadro de uma "via prussiana", ou seja, através da conciliaçáo entre fraçốes das classes dominantes, de medidas aplicadas "de cima para baixo" com a conservaçấo essencial das relaçóes de produção atrasadas (o latifúndio) e com a reprodução (ampliada) da dependência ao capitalismo internacional; essas transformaçóes "pelo alto" tiveram como causa e efeito principais a permanente tentativa de marginalizar as massas populares não só da vida social em geral, mas sobretudo do processo de formação das grandes decisôes políticas nacionais ${ }^{(8)}$. Os exemplos são inúmeros: quem proclamou nossa Independência política foi um príncipe português, numa típica manobra pelo alto"; a classe dominante do Império foi a mesma da época colonial; quem terminou capitalizando os resultados da proclamação da República (também ela proclamada "pelo alto") foi a velha oligarquia agrária; a Revolução de 1930, apesar de tudo, não passou de uma "rearrumação" do velho bloco de poder, que cooptou - e, desse modo, neutralizou e subordinou - alguns setores mais radicais das camadas médias urbanas; a burguesia industrial floresceu sob a proteção de um regime bonapartista, o Estado Novo, que assegurou pela repressão e pela demagogia a neutralizaçáo da classe operaria, ao mesmo tempo em que conservava quase intocado o poder do latifúndio, etc. Mas essa modalidade de "via prussiana" (Lênin, Lukács) ou de "revoluçáo-restauração" (Gramsci) encontrou seu ponto mais alto no atual regime militar, que criou as condiçôes políticas para a implantação em nosso País de uma modalidade dependente (e conciliada com o latifúndio) de capitalismo monopolista de Estado, radicalizando ao extremo a velha tendência a excluir tanto dos frutos do progresso quanto das decisōes políticas as grandes massas da população nacional (COUTINHO, 1979, p. 41-42).

Coutinho (1979) destaca ainda os limites dessa via, sobretudo no processo histórico de atomização da sociedade civil no Brasil, coroado por meio do golpe militar ${ }^{8}$, ao mesmo tempo em que destaca a importância das lutas pela renovaçâo democrática, ainda que num primeiro momento não ultrapassem os limites da democracia liberal. A esse respeito, o autor afirma:

Uma direta conseqüência da "via prussiana" foi gerar uma grande debilidade histórica da democracia no Brasil. Essa debilidade não se expressa apenas no plano do pensamento social (basta lembrar o caráter conciliador do nosso liberalismo), ela tem conseqüências na própria estrutura do relacionamento do 
Estado com a sociedade civil, já que ao caráter extremamente forte e autoritário do primeiro corresponde a natureza amorfa e atomizada da segunda. Essa debilidade histórico-estrutural da democracia, aliada à presença de um regime profundamente antidemocrático, faz com que o processo de renovação democrática assuma como tarefa prioritária de hoje a construção e consolidação de determinadas formas de relacionamento social que, num primeiro momento, não deverão provavelmente ultrapassar os limites da democracia liberal. Em termos de conteúdo, isso significa que as forças hegemônicas do novo regime liberal continuarão a ser, durante um certo tempo, os monopólios nacionais e internacionais, ainda que essa hegemonia seja exercida de modo menos absoluto e despótico que sob o atual regime (COUTINHO, 1979, p. 42).

A despeito desses limites, a contraposição ao Estado autoritário, expresso no país pela ditadura militar, conquistou espaços com os movimentos sociais, partidos políticos e por intermédio da busca efetiva por maior participação política e pela democratizaçáo do Estado no país, visando superar os limites advindos da ditadura militar por meio da retomada do Estado Democrático de Direito.

Nessa direção, a distensão lenta e gradual de passagem do regime militar para o civil efetivou-se mediante a eleição indireta — via colégio eleitoral — de Tancredo Neves e José Sarney, respectivamente para presidente e vice-presidente da república, efetivando-se num cenário demarcado por alta inflação e problemas sociais diversos. Esse movimento, na contramão das lutas pelas Diretas Já, consubstanciou limites ao efetivo processo de democratizaçáo do Estado e de suas políticas. Com a morte de Neves, Sarney assume a presidência em 1985.

Apesar dos limites históricos, o cenário político brasileiro avança numa perspectiva de democratização e tem, no processo constituinte e na aprovação da Constituiçáo Federal de 1988 (CF), processos de retomada do Estado Democrático de Direito, resultado de lutas históricas em prol da democracia e justiça social. A CF avança no alargamento formal da cidadania e dos direitos sociais, entre eles a educação. A dinâmica política segue, contudo, demarcando, para a maior parte da sociedade, uma cidadania tutelada, restrita e funcional ou de segunda ordem.

A eleição para a presidência da república, conquista das lutas pela democratização do Estado, é garantida pela Constituição Federal (BRASIL, 1988) e se efetiva com os limites históricos de nossa formação social. Collor de Melo foi o primeiro presidente eleito após a ditadura militar. Afastado em 2 de outubro de 1992, após instauração de seu processo de impeachment, renunciou em 29 de dezembro do mesmo ano. Em seu lugar assume Itamar Franco, cujo governo criou o plano real, tendo como ministro da Fazenda FHC, que foi eleito presidente, assumindo em janeiro de 1995, tendo sido reeleito. 
A despeito de avanços e de proposição de agenda de políticas sociais no país, por intermédio da CF de 1988, novos recuos efetivaram-se por meio da proposição de reforma do Estado no governo FHC na década de 1990 - em articulação com a nova fase de reestruturação capitalista, apoiada na geopolítica sob a égide da globalizaçáo da economia - e têm o neoliberalismo como eixo central.

Pautada por um discurso de modernização e racionalização como caminho para a retomada do desenvolvimento econômico e adequaçáo às novas demandas do processo de globalização do capital, a reforma proposta contrapóe-se ao incipiente estado de bem-estar social e suas políticas sociais. Perante esse complexo processo de democratizaçáo — diante da ditadura militar — e, ao mesmo tempo, paradoxalmente, de minimizaçáo do papel do Estado no tocante à ampliação e consolidação de políticas sociais, é fundamental ressaltar, de um lado, a agenda minimalista para as políticas públicas e forte processo de privatização em curso e, de outro, o papel e o fortalecimento de movimentos sociais, de partidos políticos e a efetivação de governos democrático-populares, sobretudo fundamentados em entes estaduais, distrital e municipais.

A partir de 2002, ocorrem importantes acenos por meio de políticas e proposiçóes do governo federal com a eleição do Presidente Lula - cuja governança, a partir de 2003, resulta de complexa coalização, envolvendo partidos de diversos matizes e ideologias —, visando à ampliação dos direitos sociais e, portanto, à materialização da CF 1988, sem romper, contudo, com o processo de globalização e suas macropolíticas direcionadas à expansão do capital, sobretudo pelo crescente processo de financeirização e dos ajustes decorrentes desse processo. Apesar desses limites, é importante ressaltar a ocorrência de avanços nas arenas tradicionais do poder político no sentido de alargamento dos direitos sociais e coletivos, entre eles, a educação nos governos Lula9 ${ }^{9}$ (2003/2010).

Entre esses avanços na área da educação, destacam-se, para o setor público, a criação do Fundo de Manutenção e Desenvolvimento da Educação Básica e de Valorização dos Profissionais da Educação (Fundeb) ${ }^{10}$; o estabelecimento de piso salarial profissional nacional para os profissionais do magistério público da educação básica pela Lei no $11.738 / 2008^{11}$; a aprovação da Emenda Constitucional no 59/2009, que instituiu a ampliaçáo da educaçáo básica obrigatória passando do ensino fundamental obrigatório para a educaçáo de 4 a 17 anos (envolvendo a obrigatoriedade da oferta e universalização do pré-escolar, do ensino fundamental e do ensino médio); a definição de que o Plano Nacional de Educação (PNE), de duração decenal, deve ser estabelecido por lei, com o objetivo de articular o Sistema Nacional de Educação em regime de colaboração e definir diretrizes, objetivos, metas e estratégias de implementação para assegurar a manutençấo e desenvolvimento do ensino em seus diversos níveis, etapas e modalidades por meio de açóes integradas dos poderes públicos das diferentes esferas federativas e o estabelecimento de meta de aplicação de recursos públicos em educação 
como proporção do produto interno bruto; a expansão e duplicação das matrículas na educação superior pública federal (criação, consolidação e interiorização de universidades e Institutos Federais). Aliado a esse processo, açóes e políticas foram desencadeadas para atender ao setor privado, tendo por centralidade o financiamento via reestruturaçáo e expansão do Fundo de Financiamento ao Estudante do Ensino Superior (FIES) ${ }^{12}$ e a criação do Programa Universidade para Todos (ProUni) ${ }^{13}$. Como esforço decorrente da Emenda Constitucional no 59/2009, o governo Lula encaminhou a proposta de PNE ao legislativo em 2010.

Eleita como a primeira mulher presidente do país, Dilma Rousseff deu continuidade às políticas em curso, sobretudo no primeiro mandato. Após intensa tramitação e com a participação ativa da sociedade civil e política por meio de envio e disputas de emendas ao texto, o projeto de PNE, em andamento desde 2010, foi aprovado no Congresso Nacional e sancionado sem vetos pela presidente Dilma Rousseff (Lei no 13.005/2014), com vigência por dez anos, em cumprimento ao disposto no Art. 214 da Constituição Federal. O PNE estabelece diretrizes e 20 metas $^{14}$, além de um conjunto de estratégias para a educação nacional.

Reeleita em 2014, a presidente iniciou seu segundo governo com forte resistência do legislativo. A despeito de ter adotado ajustes mais sintonizados às demandas do mercado, manteve compromisso com a agenda das políticas sociais, com ajustes e redução de recursos.

A materialização das metas e estratégias do $\mathrm{PNE}^{15}$ ganhou, nesse contexto, algum aceno em 2015 e primeiro semestre de 2016, com açóes e políticas direcionadas ao cumprimento do plano, tais como a aprovaçáo pelo Conselho Nacional de Educação e homologação pelo Ministério da Educação (MEC): das diretrizes curriculares nacionais para a formação dos profissionais do magistério da educação básica, por meio da Resolução CNE/CP no 2/2015 (BRASIL, 2015); das diretrizes curriculares nacionais para a formação dos funcionários da educação básica, por meio da Resolução CNE/CES no 2/2016 (BRASIL, 2016a); aprovação pelo MEC do Decreto no 8752/2016 (BRASIL, 2016b), que dispôs sobre a Política Nacional de Formação dos Profissionais da Educação Básica, em consonância com o disposto na meta 15 do PNE e de outras medidas e políticas direcionadas à materializaçáo do PNE.

Esse cenário complexo, marcado por disputas significativas entre o Congresso e o Governo Federal, agravou-se por conta do novo golpe de Estado, materializado no processo de impeachment da presidente Dilma ${ }^{16}$, e pela intensificação de políticas de ajuste fiscal conservadoras que caminham na contramão da consolidação das políticas sociais, resultando, em muitos casos, numa minimização dessas políticas.

A ascensão de Michel Temer à presidência da república em 2016, após o impeachment e apoiada em um processo de mudanças em estreita articulação às demandas 
do capital, efetivou-se por meio de uma correlação de forças direcionadas à naturalização e expansão da apropriação do fundo público pelo capital e, novamente, pela contraposição às conquistas sociais - especialmente àquelas decorrentes da Constituiçáo Federal de 1988 - expressas por políticas de ajustes neoliberais. Por meio de emendas à Constituição e reformas, o Executivo e o Legislativo, com apoio de setores dominantes, vai se desvelando um projeto societário excludente, expressão das demandas das classes dirigentes em sintonia ao movimento global de reestruturação capitalista, o que confirma a lógica excludente da burguesia nacional com o processo da formaçáo social brasileira e sua democratizaçáo. Essa opção de política econômica, característica das elites conservadoras e financeiras, afeta mais diretamente a classe trabalhadora e significou um recuo histórico, sem precedentes, no esforço histórico de democratização do Estado brasileiro. Deve ser ressaltado, no caso brasileiro, a análise e proposição feitas pela Fundação Ulysses Guimarães no programa denominado de Uma Ponte para o Futuro $^{17}$, que anunciava os caminhos da defesa de ajuste e reforma fiscal, da reforma da previdência, de emendas à Constituiçáo Federal, entre outros.

Para cumprir estes princípios será necessário um grande esforço legislativo porque as leis existentes são, em grande parte, incompatíveis com eles. Vamos precisar aprovar leis e emendas constitucionais que, preservando as conquistas autenticamente civilizatórias expressas em nossa ordem legal, aproveite os mais de 25 anos de experiência decorridos após a promulgação da Carta Magna, para corrigir suas disfuncionalidades e reordenar com mais justiça e racionalidade os termos dos conflitos distributivos arbitrados pelos processos legislativos e as açóes dos governos. Essas reformas legislativas são o primeiro passo da jornada e precisam ser feitas rapidamente, para que todos os efeitos virtuosos da nossa trajetória fiscal prevista produzam plenamente seus efeitos já no presente. Será uma grande virada institucional e a garantia da sustentabilidade fiscal, que afetarão positivamente as expectativas dos agentes econômicos, a inflaçáo futura, o nível da taxa de juros e as demais variáveis relevantes para a estabilidade financeira e o crescimento econômico (FUNDAÇÃO ULYSSES GUIMARÃES; PMDB, 2015, p. 16).

A contraposição à vinculação constitucional de recursos para a área social (educação e saúde) é explicitada no documento como um caminho a ser efetivado pelo país por intermédio de reformas, ajustes estruturais, legitimados por meio de emendas à CF 88.

Para isso é necessário em primeiro lugar acabar com as vinculações constitucionais estabelecidas, como no caso dos gastos com saúde e com educação, em razão do receio de que o Executivo pudesse contingenciar, ou mesmo cortar esses gastos em caso de necessidade, porque no Brasil o orçamento não é impositivo e o Poder Executivo pode ou náo executar a despesa orçada (FUNDAÇÃO ULYSSES GUIMARÃES; PMDB, 2015, p. 9). 
A reforma trabalhista, a aprovação da Emenda Constitucional no 95/2016 (BRASIL, 2016c) e a proposição da reforma da previdência, entre outros, expressam a adoção desse ideário como base de sustentação ao golpe parlamentar e à manutenção do governo de Michel Temer.

Com o impeachment da presidente Dilma, o PNE é secundarizado como referência de política de Estado para a educação nacional. A medida mais estruturante nessa direçâo foi a aprovação da Emenda Constitucional no 95/2016, que, ao alterar o Ato das Disposições Constitucionais Transitórias, institui o Novo Regime Fiscal e dá outras providências. Essa emenda, que vigorará por vinte exercícios financeiros, fixa limites individualizados para as despesas primárias dos órgãos integrantes daqueles orçamentos e estabelece, nos termos do $\$ 1^{\circ}$ do art. 107, o método para sua determinação. Na prática, significa o congelamento das despesas primárias, acarretando grande impacto para as políticas sociais e, neste contexto, para a educação e o cumprimento do PNE.

$\mathrm{Na}$ área educacional, a reforma do ensino médio (aprovada pela Lei $\left.\mathrm{n}^{\circ} 13.415 / 2017\right)$ e a aprovação da Base Nacional Comum Curricular ${ }^{18}$, a partir de dicotomia da educação básica, apresentam-se como importantes retrocessos na agenda educacional, inclusive na materialização do PNE.

Esse processo complexifica-se com a eleição do presidente Bolsonaro ${ }^{19}$, por meio do reforço da agenda neoliberal e ultraconservadora ${ }^{20}$, cujas sinalizaçóes e políticas caminham para o aprofundamento das políticas de ajustes neoliberais, incluindo a retomada e aprofundamento da proposta de reforma previdenciária, intensificaçáo do processo de privatizaçáo do público, retrocessos nas agendas das políticas públicas e, no campo educacional, por redirecionamento conservador das políticas para a área, pela secundarização do PNE e por expressivos cortes nos orçamentos, com especial destaque para as instituições de educação superior federais e para a educação básica pública, entre outras.

\section{Considerações finais: Estado, democracia e educação - perspectivas de lutas e resistências}

A organização e gestão da educação no Brasil, historicamente, são estruturadas por complexos arranjos institucionais, envolvendo a educação básica e superior num processo marcado pela busca de um federalismo cooperativo, não efetivado, em detrimento à lógica da guerra fiscal que ainda marca a ação dos entes federados.

A oferta da educação escolar a despeito de competências definidas constitucionalmente e da coordenação da União sofreu limites efetivos no que diz respeito à garantia de efetivo financiamento e processo de descentralizaçáo, comportando-se, na maioria das vezes, como um processo de desconcentração, em que 
as responsabilidades assumidas nem sempre se fizeram acompanhar de condições objetivas de financiamento. A assistência técnica e financeira da União, basilar nesse processo, vem sofrendo cortes. Considerando os indicadores de matrículas (líquida e bruta), a educação superior ainda é considerada de elite, apesar dos processos de expansão vivenciados nos últimos anos. Esse nível de ensino é predominantemente privado (respondendo por $75 \%$ das matrículas) ${ }^{21}$, ainda que tenha havido a duplicação de matrículas efetivadas no ensino superior público federal na última década.

$\mathrm{Na}$ educação básica, majoritariamente ofertada por estados, Distrito Federal e municípios ${ }^{22}$, assiste-se a complexos processos de privatização do público, sobretudo por alteraçôes nas formas de gestão e organização desse nível educacional por meio de parcerias público-privadas (consultorias, assessorias, organizaçóes sociais) e pela criação de escolas militares. É importante salientar, atualmente, a defesa das escolas militares em vários programas de governo envolvendo governos federal, estaduais, distrital e municipais. A definição constitucional de garantia da universalização da educação básica até 2016, por meio da EC no 49/2009 e do PNE, não se efetivou, e o país apresenta sérios desafios no tocante à universalizaçâo do pré-escolar (4-5 anos) e, sobretudo, ao ensino médio.

Aprofundando o cenário de retrocessos no campo das políticas sociais, o governo Bolsonaro, além de propor a manutenção da Emenda Constitucional no 95/2016, que inviabiliza a materialização do PNE, retrocede ainda mais na agenda para a educaçáo, com uma retomada conservadora e sem precedentes nas políticas, mediante um discurso de intolerância ao marxismo, a Paulo Freire e à diversidade; pela ênfase na educação a distância na educação básica; pela defesa das escolas militares, entre outros.

A respeito do movimento conservador de direita na educação, a análise de Apple (2003) é singular ao descortinar seus objetivos e pode auxiliar-nos na compreensão desse movimento em curso no país.

Segundo o autor:

Um dos objetos mais importantes da atuação direitista é mudar nosso senso comum, alterando o significado das categorias mais básicas, as palavras-chave que empregamos para compreender o mundo social e educacional e o nosso lugar nele. De muitas formas, um aspecto crucial dessa atuação diz respeito ao que tem sido chamado política de identidade. A tarefa é alterar radicalmente aquilo que pensamos ser e como nossas principais instituiçóes devem responder a essa alteração de identidade (APPLE, 2003, p. 11).

Esse conservadorismo em educação no Brasil, que se efetiva no país, merece estudo particular para identificar as suas imbricaçôes com o mercado, a 
religiấo e novos padróes societários. Nas ações do governo federal, tais imbricações parecem presentes, merecendo, contudo, uma análise a ser aprofundada. O governo Bolsonaro, nessa direção, tem desferido várias sinalizações envolvendo: críticas ao papel e finalidades das universidades públicas, atacando sua eficiência e impondo restriçóes à sua autonomia; questionamentos sobre conhecimento científico e sobre o papel e finalidades da educação escolar; questionamentos e busca de controle sobre os profissionais da educaçáo (movimentos como lei da mordaça/Escola sem Partido ${ }^{23}$, que avançam nos poderes legislativos e executivos do país); redução drástica de recursos para a educação básica e superior, entre outros.

É nesse cenário que se situam os desafios para a educação nacional no que concerne à garantia de acesso e permanência com qualidade social, num estado com enorme dívida social no campo educacional e que apresenta riscos no tocante à manutenção do Estado Democrático de Direito, como preconizado na Constituição Federal de 1988.

Nesse cenário, reafirmar a CF de 1988 é vital. Conhecida como a Constituição Cidadã (perante a garantia dos direitos humanos, sociais e de trabalho para a população brasileira), esta CF ratifica a democratização da República Federativa envolvendo os princípios fundamentais; as garantias e os direitos fundamentais; a própria organização do estado; a organização dos poderes; "Defesa do Estado e das Instituições", a definição de regras para tributação e orçamento; a ordem econômica e financeira; a ordem social, além das disposiçóes gerais.

Nessa direção, reafirmar a CF dando realce para o art. $1^{\circ}$, que define que a República Federativa do Brasil, formada pela união indissolúvel dos Estados, Municípios e Distrito Federal, constitui-se em Estado Democrático de Direito e tem como fundamentos: a soberania; a cidadania; a dignidade da pessoa humana; os valores sociais do trabalho e da livre iniciativa; o pluralismo político, é vital para a retomada da democratizaçáo do Estado.

No que tange aos direitos sociais à educação, a luta em defesa dos artigos 205 a 214 da CF é fundante na medida em que estes resguardam: dever do Estado para com a educação; os princípios com os quais o ensino será ministrado; igualdade de condiçóes para o acesso e permanência na escola; liberdade de aprender, ensinar, pesquisar e divulgar o pensamento, a arte e o saber; pluralismo de ideias e de concepçóes pedagógicas, e coexistência de instituiçóes públicas e privadas de ensino; gratuidade do ensino público em estabelecimentos oficiais; valorizaçáo dos profissionais da educação escolar, garantidos, na forma da lei, planos de carreira, com ingresso exclusivamente por concurso público de provas e títulos aos das redes públicas; garantia de padrão de qualidade; piso salarial profissional nacional para os profissionais da educaçáo escolar pública, nos termos de lei federal; planos de carreira; a garantia às universidades da autonomia didático-científica, administrativa e de gestão financeira e patrimonial e ao princípio de indissociabilidade entre ensino, pesquisa e extensão; a definição de que o dever do Estado com a 
educação será efetivado mediante a garantia, entre outros, de: educação básica obrigatória e gratuita dos 4 aos 17 anos de idade, e o acesso ao ensino obrigatório e gratuito é direito público subjetivo; a definição de que ensino é livre à iniciativa privada, atendidas as seguintes condiçóes: cumprimento das normas gerais da educação nacional e autorização e avaliação de qualidade pelo Poder Público; a definição de que serão fixados conteúdos mínimos para o ensino fundamental, de maneira a assegurar formação básica comum e respeito aos valores culturais e artísticos, nacionais e regionais; a definição de que a União, os estados, o Distrito Federal e os municípios organizarão seus sistemas de ensino em regime de colaboraçáo, incluindo que a Uniáo organizará o sistema federal de ensino e o dos Territórios, financiará as instituições de ensino públicas federais e exercerá, em matéria educacional, função redistributiva e supletiva, de forma a garantir equalização de oportunidades educacionais e padrão mínimo de qualidade do ensino mediante assistência técnica e financeira aos estados, ao Distrito Federal e aos municípios; a definição de que os municípios atuarão prioritariamente no Ensino Fundamental e na educação infantil e os estados e o Distrito Federal atuarão prioritariamente no ensino fundamental e médio; a definição de que, na organização de seus sistemas de ensino, a União, os estados, o Distrito Federal e os municípios definirão formas de colaboração, de modo a assegurar a universalizaçáo do ensino obrigatório; a definição de que a educação básica pública atenderá prioritariamente ao ensino regular; a definição da vinculação constitucional de recursos ao definir que a União aplicará, anualmente, nunca menos de 18, e os Estados, o Distrito Federal e os Municípios $25 \%$, no mínimo, da receita resultante de impostos, compreendida a proveniente de transferências, na manutenção e desenvolvimento do ensino; a definição de que os recursos públicos serão destinados às escolas públicas, podendo ser dirigidos a escolas comunitárias, confessionais ou filantrópicas, definidas em lei, que: comprovem finalidade náo lucrativa e apliquem seus excedentes financeiros em educação, assegurem a destinação de seu patrimônio a outra escola comunitária, filantrópica ou confessional, ou ao Poder Público, no caso de encerramento de suas atividade; o estabelecimento do PNE, de duraçáo decenal, com o objetivo de articular o sistema nacional de educação em regime de colaboração e definir diretrizes, objetivos, metas e estratégias de implementação para assegurar a manutenção e desenvolvimento do ensino em seus diversos níveis, etapas e modalidades por meio de açóes integradas dos poderes públicos das diferentes esferas federativas que conduzam a: erradicação do analfabetismo; universalização do atendimento escolar; melhoria da qualidade do ensino; a garantia de formação para o trabalho, bem como de promoção humanística, científica e tecnológica do país, o estabelecimento de meta de aplicação de recursos públicos em educação como proporção do produto interno bruto.

Boa parte dessas definições constitucionais está posta em questionamento pelo governo federal, incluindo o dever do Estado com a educação, a garantia dos princípios basilares ao ensino (projetos como o Escola com Mordaça/Escola 
sem Partido e tentativa de denúncias visando reduzir a autonomia docente expressam esse movimento conservador no campo); propostas de quebra da gratuidade (especialmente no ensino superior), restriçóes a autonomia universitária (decretos, cortes de orçamentos, proposta de nova governança das IFES pelo MEC [Futurese]); ação centralizada da União na contramão do estímulo ao regime de colaboração entre os sistemas de ensino, redução da função redistributiva e supletiva, mediante assistência técnica e financeira aos estados, ao Distrito Federal e aos municípios, explicitada pelos cortes efetivados pela União dos recursos a serem repassados para a educação básica; discussões, sob a égide fiscal, da necessidade de ruptura com a vinculação constitucional de recursos para a educação (proposta que já se apresentava no projeto Uma Ponte para o Futuro); a secundarização do PNE, de suas diretrizes, metas e estratégias, a redução dos recursos para a educação e os efeitos das políticas em curso complementadas pelos efeitos da EC no 95/2016 devem, a meu juízo, contribuir para que os movimentos sociais, partidos políticos, sindicatos e outros setores mobilizem-se na busca de uma unidade programática que inclua a defesa intransigente do Estado Democrático de Direito, da CF Carta Magna do país - e do PNE como epicentro das políticas educativas.

A CF tem importância política e estratégica para o estabelecimento de políticas de Estado para as públicas, e o PNE - a despeito de alguns limites que demarcaram o plano, sobretudo no que concerne às metas e estratégias relativas à avaliação, à diversidade e ao financiamento - em articulação com a CF, nesse contexto, para a educação básica e superior. Essa importância política revela-se ainda mais no atual cenário conservador e neoliberal, cuja conjuntura vem contribuindo para uma regressão da agenda das políticas públicas e, no campo educacional, para a não materialização do plano como política pública de Estado, tendo em vista a opção por uma política regressiva de ajustes de toda ordem na contramão da efetivação de políticas direcionadas à garantia de direitos sociais.

A luta pela materialização da CF e do PNE implica, portanto, a garantia do Estado Democrático de Direito, na preservação do fundo público, na revogação da EC95/2016, na defesa da vinculação constitucional de recursos, na revogação da reforma do ensino médio e da Base Nacional Comum Curricular, na preservação do caráter público, gratuito, laico, inclusivo e democrático do sistema; na regulamentação de algumas diretrizes, metas e estratégias do PNE (resultando, entre outras, na priorização dos investimentos em educação e definição em torno do Custo Aluno-Qualidade Inicial e Custo Aluno-Qualidade, nas políticas de expansão da educação básica e superior pública, na valorização dos profissionais da educação); na ampliação dos recursos para a educação, visando atingir a meta de 10\% do PIB até 2024; em maior organicidade na relação de cooperação e colaboração entre os entes federados (União, estados, Distrito Federal e municípios) que garanta os meios de acesso à educação (Art. 23, inciso $\mathrm{V}$, parágrafo único da $\mathrm{CF})$, bem como de políticas e gestáo que considerem as especificidades do sistema educacional brasileiro, seus níveis, etapas e modalidades, os processos de gestão, 
avaliação, financiamento, qualidade e delineamento de concepçóes político-pedagógicas norteadoras, entre outros.

A reversão desse cenário de retrocessos requer a busca por políticas e ações, envolvendo a sociedade civil e política, mediante alteração substantiva da agenda política, econômica e educacional vigentes no país. A retomada do Estado Democrático de Direito, tendo por centralidade a ampliação dos direitos sociais e sua materialização por meio de políticas sociais de Estado implica, portanto, numa ruptura mais profunda com a dinâmica sociopolítica brasileira, pautada por um "desenvolvimento desigual e combinado" delineado neste artigo, remetendo-nos a uma análise dialética do processo histórico brasileiro, buscando superar os limites da modernização conservadora excludente, acentuadas pelas políticas e processos atuais e seus desdobramentos, visando à constituição de uma formação social brasileira democrática, com o fortalecimento e engajamento da sociedade civil na defesa da democracia como valor essencial ${ }^{24}$ e universal.

Nessa direção, retomo as proposições de Coutinho (1979), pensadas em outro contexto histórico, mas que se mostram atuais, para avançarmos no sentido da construção da democracia e nos afastarmos de qualquer tentação golpista ou militarista.

A luta pela renovação democrática - precisamente por recorrer a "guerra de posição" como método e por afastar resolutamente qualquer tentação "golpista" ou "militarista" — implica em conceber a unidade como valor estratégico. Já nos referimos ao fato de que o necessário pluralismo dos sujeitos coletivos de base degenera em formas de corporativismo quando não se verifica um processo de unificação política, através da mediação dos organismos representativos de âmbito nacional; por outro lado, a democracia de massas - enquanto democracia real - pressupóe que a conquista a hegemonia se faça através da obtenção do consenso majoritário das correntes políticas e das classes e camadas sociais. (Talvez não seja inútil lembrar que maioria implica minoria, cujos direitos - na medida em que sua ação oposicionista não viole a legalidade constitucional democraticamente fundada - teráo de ser respeitados.) Mas essa afirmação do valor estratégico da unidade ganha um traço concreto específico quando referido ao Brasil: a tarefa da renovação democrática implica a crescente socialização da política, a incorporação permanente e anti-"prussiana" de novos sujeitos individuais e coletivos ao processo de transformação da realidade. Como a autonomia e a diversidade desses sujeitos deverão ser respeitadas, a batalha pela unidade — uma unidade na diversidade — torna-se não apenas um objetivo tático imediato na luta pelo fim do atual regime, mas também um objetivo estratégico no longo caminho para "elevar a nível superior” a democracia (COUTINHO, 1979, p. 45). 


\section{Notas}

1. A concepção de Estado ampliado de Gramsci (1978) adotada neste artigo não se reduz ao governo, constituindo-se, ele mesmo, na expressão das relaçóes sociais contraditórias, por meio de atividades e ações políticas (práticas e teóricas) em que, de um lado, as classes dirigentes se mantêm e se justificam e, de outro, servem de espaço e força efetiva para a consciência e organização das classes dominadas. Ou seja, Estado ampliado ou integral Estado, tendo por eixo a concepção gramsciana, é expressão da correlação de forças contraditórias, estendendo-se além dos limites da classe dominante, com base na força e do consenso, ou seja, da hegemonia encouraçada de coerção.

2. Bastos (2013, p. 1-2) conceitua a financeirização como modus operandi sistêmico e de escopo mundial ao afirmar que: "Pode-se conceituar a financeirização como o modo atual de funcionamento do capitalismo global, originado na década de 1980, contemporâneo da mundialização financeira. Esse modo é marcado pela importância da lógica da especulação, ou seja, por decisóes de compra (venda) de ativos comandadas pela expectativa de revenda (recompra) com lucros em mercados secundários de açôes, imóveis, moedas, créditos, commodities e vários outros ativos. A financeirização é sistêmica e de escopo mundial, vale dizer, impacta as relaçôes econômicas internacionais e as torna crescente transnacional, atravessada por fluxos de capital transfronteiriços capazes de influenciar o comportamento de economias nacionais. Isso náo quer dizer que todos os países integrados à economia mundial capitalista experimentam o mesmo grau de aprofundamento da financeirização, mas bancos, empresas, grandes investidores e famílias (por meio de investidores institucionais) tendem a ser atraídas pelos ganhos esperados pelas atividades especulativas que influenciam a própria estrutura de setores econômicos e dos mercados de câmbio, commodities e de trabalho. Os Estados passaram a depender mais das receitas tributárias geradas pelos movimentos de expansão financeira, porém experimentam desequilíbrios fiscais severos depois das crises financeiras verificadas regularmente desde a década de 1980" (BASTOS, 2013, p. 1-2, grifos nossos).

3. Segundo Mészaros (2002, p. 1072), a reestruturação da economia opera "confinada às determinaçôes objetivas e aos mecanismos de controle do capital que favorecem apenas a ele e nada mais", e efetiva-se por meio de embates e resistências. Nessa direção, considerando a complexidade desse processo, ratificamos, ainda, a concepção de Ianni (2004, p. 57) de que o "capital em geral, lógica e historicamente, se constitui no âmbito mundial e não no da nação. É obvio que as relaçóes, processos e estruturas compreendidos ou influenciados pelos movimentos do capital em geral afetam o modo pelo qual a sociedade e o Estado se encontram e se desencontram".

4. Segundo Ianni (2004, p. 21-22): "As campanhas abolicionista e republicana mobilizaram forças empenhadas em mudanças políticas e sociais. Além dos objetivos humanitários, quanto ao término do regime de trabalho escravo, abolicionistas e republicanos associaram-se na luta por conquistas democráticas. Havia setores sociais urbanos empenhados em democratizar o poder estatal e as relaçôes sociais. [...] Mas o que venceu foi o interesse da cafeicultura do oeste paulista, em aliança com a dos canavieiros, pecuária, seringais e outros, em diversas regiôes do país. 
Prevaleceram os interesses de setores burgueses emergentes, combinados com os preexistentes, remanescentes".

5. Segundo Ianni (2004, p. 29): "Foi na década de 30 que se formularam as principais interpretações do Brasil Moderno, configurando 'uma compreensão mais exata do país'. Muito do que se pensou antes se polariza e se decanta nessa época. E muito do que se pensa depois arranca das interpretações formuladas até entâo. [...] Naquela época formularam-se algumas matrizes do pensamento social brasileiro, no que se refere a questôes básicas: a vocação agrária e as possibilidades de industrialização, o capitalismo nacional e associado, o federalismo e o centralismo, o civismo e o militarismo, a democracia e o autoritarismo, a região e a nação, a multiplicidade racial e a formação do povo, o capitalismo e o socialismo, a modernidade e a tradiçáo”.

6. Pires e Ramos (2009) desenvolvem importante ensaio teórico sobre a concepção de modernização conservadora, a partir de literatura internacional e nacional, e afirmam: "Em linhas gerais, o termo modernização conservadora foi elaborado por Moore Junior (1975) para retratar o caso específico de desenvolvimento capitalista na Alemanha e no Japão, os quais realizaram revoluções burguesas vindas de cima. Assim, o processo de modernização de sua sociedade alicerçou-se sobre um processo de industrialização condicionado pelo pacto político tecido entre a burguesia e os terratenentes. Não obstante, o elemento que diferencia o processo de modernização conservadora no Brasil vis-à-vis ao caso alemáo e japonês deve-se ao fato de que a elite dominante nacional não teve a preocupação em expandir a cidadania para parcelas significativas da população, ao contrário do caso alemão e japonês, que incorporou as classes inferiores à sociedade" (PIRES; RAMOS, 2009, p. 420).

7. A respeito da democracia, é fundamental ver Bobbio et al. (2002). Esse autor ressalta que confluem três grandes tradições do pensamento político sobre democracia: a teoria clássica, a medieval e a moderna. Outra discussão importante feita pelo teórico é a distinção entre a "democracia formal" e a "democracia substancial", ao afirmar: "A primeira indica um certo número de meios questáo precisamente as regras de comportamento [...] independente da consideração dos fins. A segunda indica um conjunto de fins, entre os quais, sobressai o fim da igualdade jurídica, social e econômica, independente dos meios adotados para os alcançar" (BOBBIO et al., 2002, p. 329). Com base no cenário brasileiro, Coutinho (1979) contribui para avançar a discussão, ao situar a democracia como valor universal. A discussão sobre os sentidos da democracia ganham relevo na coletânea organizada por Oliveira e Paoli (2000).

8. Coutinho (2000, p. 32), ao se referir ao golpe de 1964 como uma solução "prussiana" que conseguiu truncar o processo de democratização à época, afirma: "O novo regime ditatorial, particularmente no período que se seguiu ao AI-5, tentou por todos os meios destroçar o embriáo da sociedade civil autnônoma que vinha se esboçando. E é evidente que a organização da cultura não foi poupada. Não é casual que, entre as primeiras medidas do regime ditatorial implantado em 1964, estivesse o fechamento dos principais institutos democráticos de organização cultural da época, os CPCs e o ISEB, bem como a dissolução do Camando dos Trabalhadores intectuais (o CTI)" (COUTINHO, 2000, p. 32). Coutinho (2000, p. 257) afirma que, "com base em seu conceito de revolução burguesa de tipo 'não clássico', Florestan não só reexaminou momentos essenciais do nosso passado, mas também propôs uma brilhante interpretação marxista — uma 
das mais lucidas de que disomos — daquilo que, na época em que RBB foi publicado, constituía o nosso presente histórico. [...] Mas sabemos agora, graças entre outras coisas ao radicalismo de Florestan, que a esquerda brasileira não pode travar essa luta se não se libertar de uma dupla ilusão: por um lado, a de que os avanços obtidos na construção de nossa democracia já estejam definitivamente consolidados, mesmo no nível da superestrutura política e, por outro, a de que, ainda que consigamos consolidar, tais avanços sejam suficientes para realizar a verdadeira emancipação humana de nosso povo. A democracia que começamos a construir na época da transição só se consolidará de modo definitivo e só se realizará plenamente como valor universal no horizonte da progressiva radicalização, ou seja, da sua transformação em democracia socialista”.

9. A respeito de análise dos governos Lula e Dilma, ver Sader (2013).

10. O Fundeb, envolvendo o financiamento de todas as etapas e modalidades da educação básica, foi criado pela Emenda Constitucional no 53/2006 e regulamentado pela Lei no 11.494/2007 e pelo Decreto no 6.253/2007, em substituição ao Fundo de Manutenção e Desenvolvimento do Ensino Fundamental e de Valorização do Magistério (Fundef), que vigorou de 1998 a 2006 e se direcionava ao Ensino fundamental.

11. A Lei no $11.738 / 2008$, após o reconhecimento de sua constitucionalidade pelo Supremo Tribunal Federal, passou a ter validade nacional, obrigando a todos os entes federativos ao cumprimento da Lei do Piso.

12. O Fies é um programa do Ministério da Educação destinado a financiar estudantes de cursos de graduação regularmente matriculados em instituições de ensino não gratuitas cadastradas no programa.

13. O ProUni, criado pela Lei no 11.096 , de 13 de janeiro de 2005, é um programa do governo fede$\mathrm{ral} / \mathrm{MEC}$ que concede bolsas de estudo integrais e parciais de $50 \%$ a estudantes em instituiçóes privadas de educação superior, em cursos de graduação e sequenciais de formação específica.

14. O PNE aprovou 20 metas e mais de uma centena de estratégias. Para efeito didático, as metas são apresentadas a seguir por níveis de educação e temáticas, sugeridas pelo autor, a partir da Lei $\mathrm{n}^{\circ}$ 13.005/2014 (BRASIL, 2014): A) Educação básica: Meta 1: universalizar, até 2016, a educação infantil na pré-escola para as crianças de 4 a 5 anos de idade e ampliar a oferta de educação infantil em creches de forma a atender, no mínimo, $50 \%$ das crianças de até 3 anos até o fim da vigência deste PNE; Meta 2: universalizar o ensino fundamental de 9 anos para toda a populaçáo de 6 a 14 anos e garantir que pelo menos $95 \%$ dos alunos concluam essa etapa na idade recomendada, até o último ano de vigência deste PNE; Meta 3: universalizar, até 2016, o atendimento escolar para toda a populaçáo de 15 a 17 anos e elevar, até o fim do período de vigência deste PNE, a taxa líquida de matrículas no ensino médio para 85\%; Meta 4: universalizar, para a população de 4 a 17 anos com deficiência, transtornos globais do desenvolvimento e altas habilidades ou superdotação, o acesso à educação básica e ao atendimento educacional especializado, preferencialmente na rede regular de ensino, com a garantia de sistema educacional inclusivo, de salas de recursos multifuncionais, classes, escolas ou serviços especializados, públicos ou conveniados; Meta 5: alfabetizar todas as crianças, no máximo, até o fim do $3^{\circ}$ ano do ensino fundamental; Meta 6: oferecer educação em tempo integral em, no mínimo, $50 \%$ das escolas públicas, de forma a atender, pelo menos, $25 \%$ dos(as) alunos(as) 
da educação básica; Meta 7: fomentar a qualidade da educação básica em todas as etapas e modalidades, com melhoria do fluxo escolar e da aprendizagem de modo a atingir as seguintes médias nacionais; Meta 8: elevar a escolaridade média da população de 18 a 29 anos, de modo a alcançar, no mínimo, 12 anos de estudo no último ano de vigência desse plano, para as populaçóes do campo, da regiáo de menor escolaridade no país e dos $25 \%$ mais pobres, e igualar a escolaridade média entre negros e não negros declarados à Fundação Instituto Brasileiro de Geografia e Estatística (IBGE); Meta 9: elevar a taxa de alfabetização da população com 15 anos ou mais para 93,5\% até 2015 e, até o fim da vigência desse PNE, erradicar o analfabetismo absoluto e reduzir em $50 \%$ a taxa de analfabetismo funcional; Meta 10: oferecer, no mínimo, 25\% das matrículas de educação de jovens e adultos, nos ensinos fundamental e médio, na forma integrada à educação profissional; Meta 11: triplicar as matrículas da educaçáo profissional técnica de nível médio, assegurando a qualidade da oferta e pelo menos 50\% da expansão no segmento público; B) Educação superior: Meta 12: elevar a taxa bruta de matrícula na educaçáo superior para $50 \%$ e a taxa líquida para $33 \%$ da população de 18 a 24 anos, assegurada a qualidade da oferta e expansão para, pelo menos, $40 \%$ das novas matrículas, no segmento público; Meta 13: elevar a qualidade da educação superior e ampliar a proporçáo de mestres e doutores do corpo docente em efetivo exercício no conjunto do sistema de educaçáo superior para 75\%, sendo, do total, no mínimo, 35\% doutores; Meta 14: elevar gradualmente o número de matrículas na pós-graduação stricto sensu, de modo a atingir a titulação anual de 60 mil mestres e 25 mil doutores; C) Valorização dos profissionais da educação Meta 15: garantir, em regime de colaboração entre a Uniáo, os estados, o Distrito Federal e os municípios, no prazo de um ano de vigência desse PNE, política nacional de formação dos profissionais da educação de que tratam os incisos I, II e III do caput do art. 61 da Lei no 9.394, de 20 de dezembro de 1996 (BRASIL, 1996), assegurado que todos os professores e as professoras da educação básica possuam formação específica de nível superior, obtida em curso de licenciatura na área de conhecimento em que atuam; Meta 16: formar, em nível de pós-graduação, $50 \%$ dos professores da educação básica, até o último ano de vigência deste PNE, e garantir a todos(as) os(as) profissionais da educaçáo básica formação continuada em sua área de atuação, considerando as necessidades, demandas e contextualizaçóes dos sistemas de ensino; Meta 17: valorizar os(as) profissionais do magistério das redes públicas de educação básica de forma a equiparar seu rendimento médio ao dos(as) demais profissionais com escolaridade equivalente, até o fim do sexto ano de vigência deste PNE; Meta 18: assegurar, no prazo de dois anos, a existência de planos de carreira para os(as) profissionais da educaçáo básica e superior pública de todos os sistemas de ensino e, para o plano de carreira dos(as) profissionais da educação básica pública, tomar como referência o piso salarial nacional profissional, definido em lei federal, nos termos do inciso VIII do art. 206 da Constituiçáo Federal; D) Gestáo Democrática: Meta 19: assegurar condiçóes, no prazo de dois anos, para a efetivação da gestão democrática da educaçáo, associada a critérios técnicos de mérito e desempenho e à consulta pública à comunidade escolar, no âmbito das escolas públicas, prevendo recursos e apoio técnico da União para tanto; E) Financiamento: Meta 20: ampliar o investimento público em educação pública de forma a atingir, no mínimo, o patamar de $7 \%$ do produto interno bruto (PIB) do país no $5^{\circ}$ ano de vigência desta Lei e, no mínimo, o equivalente a 10\% do PIB ao final do decênio.

15. A respeito do PNE e de sua materialização ou dos limites interpostos a este processo, ver Dourado (2017). 
16. O impeachment da Presidente Dilma Rousseff iniciou-se com a aceitação, em 2 de dezembro de 2015, pelo presidente da Câmara dos Deputados, de denúncia por crime de responsabilidade e resultou na cassação do mandato no dia 31 de agosto de 2016. Após a cassaçấo do mandato, o vice-presidente Michel Temer assumiu a presidência da república. O processo de impeachment e seus desdobramentos, que causou impactos na democracia e no Estado de Direito no país, vêm sendo entendidos, por intelectuais e políticos, como Golpe de Estado. A esse respeito, ver Souza (2016).

17. A respeito, ver: Fundação Ulysses Guimarães e PMDB (2015).

18. A esse respeito, ver, entre outros, Aguiar e Dourado (2018).

19. Sobre o cenário atual brasileiro, Levy (2018) faz uma importante sinalização ao afirmar que é apenas uma frente de uma guerra global: "Há uma luta ideológica entre o humanismo, entre os extremos, da esquerda à direita, que se alinharam nas ruas para destruir os valores republicanos e as forças do progresso [...]. O Brasil está dentro dessa corrente global e, de certo modo, seu líder populista é o mais caricatural de todos". Nesse cenário, o autor afirma que "a vitória de Bolsonaro é uma derrota da esquerda, mas é uma derrota muito mais importante da direita. Bolsonaro a devorou. Essa direita liberal, limpa, republicana, que quis construir um país de costas para a ditadura, essa direita é o objetivo principal de Bolsonaro. Ele quer acabar com ela e em parte conseguiu. Hoje ela está fora do jogo" (LEVY, 2018, n.p.).

20. A esse respeito, ver O Caminho da Prosperidade (2018) e também análise sobre educação no referido plano, disponível em: <http://www.anped.org.br/news/jair-bolsonaro-psl-analise-de-programa-de-educacao $>$. Acesso em: 13 mar. 2019.

21. Segundo dados de matrículas, no Censo da Educaçáo Superior do Inep de 2017 (BRASIL, 2017), o setor privado responde por 6.241.307 de um total de 8.268.663 matrículas do ensino de graduação presencial e a distância, e o setor público responde por apenas 2.045 .356 matrículas (1.306.351 público federal, 641.865 nas estaduais e 97.140 nas IES municipais).

22. Segundo dados de matrículas, no Censo da Educação Superior do Inep de 2017, o setor público responde por $81,7 \%$ das 48.608 .093 matrículas da educaçáo básica, apesar dos complexos processos de interpenetração entre os setores público e privado.

23. A respeito, ver Frigotto (2016).

24. Sobre a democracia no cenário atual, que possamos construir um muro da democracia como proposto por Levy (2018, n.p.) ao afirmar: "O sonho de muitos líderes é acabar com a democracia. Trump, Bolsonaro, [Viktor] Orban na Hungria. Mas nos Estados Unidos estamos vendo até que ponto a democracia é capaz de resistir. $\mathrm{O}$ verdadeiro muro americano não é o que Trump quer construir entre os Estados Unidos e o México, mas o que a sociedade civil norte-americana construiu para ele. Trump não é livre para fazer o que quer e está dando cabeçadas na parede. Talvez isso acabe quebrando a cabeça dele, vamos ver. E o que eu desejo para o Brasil é algo parecido, que se revele um muro da democracia e enfrente a vulgaridade, a estupidez e a ausência de ideias". 


\section{Referências}

AGUIAR, M.A.S.; DOURADO, L.F. (orgs.). A BNCC na contramão do PNE 20142024: avaliação e perspectivas. Recife: ANPAE, 2018.

APPLE, M.W. Educando a direita. Mercados, Padrôes, Deus e Desigualdade. São Paulo: Cortez; Instituto Paulo Freire, 2003.

BASTOS, P.P.Z. Financeirizaçáo, crise, educação: consideraçóes preliminares. Campinas: Unicamp, 2013. (Texto para Discussão, n. 217).

BOBBIO, N. et al. Dicionário de Política. Brasília: Editora Universidade de Brasília, 1992.

Brasil. Instituto Nacional de Estudos e Pesquisas Educacionais Anísio Teixeira. Censo da Educaçáo Superior do Inep de 2017. Inep, 2017.Disponível em: < http://download.inep. gov.br/educacao_superior/censo_superior/documentos/2019/press-kit_censo_educacao_ superior2018.pdf>. Acesso em: 30 mar. 2019.

BRASIL. Conselho Nacional de Educação. Resoluçáo CNE/CES no 2, de 2016. Define as Diretrizes Curriculares Nacionais para a Formação Inicial e Continuada em Nível Superior para Funcionários da Educação Básica. Brasil, 2016a. Disponível em: <http://portal.mec. gov.br/index.php?option=com_docman \&view=download \&alias=41081-rces002-16pdf\&category_slug=maio-2016-pdf\&Itemid=30192>. Acesso em: 20 dez. 2018.

BRASIL. Conselho Nacional de Educação. Resoluçáo CNE/CP no 2, de $1^{\circ}$ de julho de 2015. Define as Diretrizes Curriculares Nacionais para a formação inicial em nível superior (cursos de licenciatura, cursos de formação pedagógica para graduados e cursos de segunda licenciatura) e para a formação continuada. Brasil, 2015.

BRASIL. Decreto no 8.752, de 9 de maio 2016. Dispóe sobre a Política Nacional de Formação dos Profissionais da Educação Básica. Brasil, 2016b. Disponível em: <http://www.planalto.gov.br/ccivil_03/_Ato2015-2018/2016/Decreto/D8752.htm>. Acesso em: 20 fev. 2019.

BRASIL. Emenda Constitucional no 95, de 15 de dezembro de 2016. Altera o Ato das Disposiçóes Constitucionais Transitórias, para instituir o Novo Regime Fiscal, e dá outras providências. Brasil, 2016c. Disponível em: <http://www.planalto.gov.br/ccivil_03/ constituicao/emendas/emc/emc95.htm>. Acesso em: 20 fev. 2019.

BRASIL. Inep. Censo da Educaçáo Superior do Inep de 2017. Brasil, 2018. Disponível em: <http://download.inep.gov.br/educacao_superior/censo_superior/documentos/2019/presskit_censo_educacao_superior2018.pdf>. Acesso em: 30 mar. 2019.

BRASIL. Lei no 9.394, de 20 de dezembro de 1996. Estabelece as diretrizes e bases da educação nacional. Brasil, 1996. Disponível em: <http://www.planalto.gov.br/ccivil_03/ leis/L9394.htm>. Acesso em: 16 out. 2018.

BRASIL. Lei no 13.005, de 25 de junho de 2014. Aprova o Plano Nacional de Educação PNE e dá outras providências. Brasil, 2014. Disponível em: <http://www.planalto.gov.br/ CCIVIL_03/_Ato2011-2014/2014/Lei/L13005.htm>. Acesso em: 16 out. 2018. 
BRASIL. Planalto. Casa Civil. Emenda Constitucional no 59, de 11 de novembro de 2009. Brasília, 2009. Disponível em: <http://www.planalto.gov.br/ccivil_03/constituicao/ Emendas/Emc/emc59.html>. Acesso em: 20 dez. 2018.

BRASIL. Presidência da República. Casa Civil. Constituição da República Federativa do Brasil de 1988. Brasil, 1988. Disponível em: <http://www.planalto.gov.br/ccivil_03/ Constituicao/Constituicao.htm>. Acesso em: 16 out. 2018.

COUTINHO, C.N. A democracia como valor universal. p. 33-47, 1979. Disponível em: <https://www.marxists.org/portugues/coutinho/1979/mes/democracia.htm>. Acesso em: 20 dez. 2018.

COUTINHO, C.N. Cultura e sociedade no Brasil. Ensaio sobre ideias e formas. Rio de Janeiro: DP\&A, 2000. 272 p.

DOURADO, L.F. Plano Nacional de Educaçáo: o epicentro das políticas de Estado para a educação brasileira. Política de Estado para a educação brasileira. Goiânia: Imprensa Universitária/ANPAE, 2017. 216 p.

FRIGOTTO, G. Escola sem Partido: imposição da mordaça aos educadores. e-Mosaicos, Rio de Janeiro, v. 5, n. 9, 2016.

FUNDAÇÃO ULYSSES GUIMARÃES; PARTIDO DO MOVIMENTO DEMOCRÁTICO BRASILEIRO (PMDB). Uma ponte para o futuro. Brasília: Fundação Ulisses Guimarães, 2015. Disponível em: <https://www.fundacaoulysses.org. br/wp-content/uploads/2016/11/UMA-PONTE-PARA-O-FUTURO.pdf>. Acesso em: 20 dez. 2018.

GRAMSCI, A. Concepção dialética da história. Rio de Janeiro: Civilização Brasileira, 1978.

IANNI, O. A idéia de Brasil Moderno. São Paulo: Brasiliense, 2004.

LÉVY, B.-H. Bolsonaro derrotou mais a direita do que a esquerda. Jornal El Pais, São Paulo, 26 nov. 2018. Disponível em: <https://brasil.elpais.com/brasil/2018/11/25/ politica/1543176331_063342.html>. Acesso em: 13 mar. 2019.

MÉSZAROS, I. Para além do capital. São Paulo: Boitempo; Campinas: Editora da Unicamp, 2002.

O CAMINHO DA PROSPERIDADE. Proposta de Plano de Governo Bolsonaro. 2018. Disponível em: <https://flaviobolsonaro.com/PLANO_DE_GOVERNO_JAIR_ BOLSONARO_2018.pdf>. Acesso em: 30 mar. 2019.

OLIVEIRA, F; PAOLI, M.C. (orgs.) Os sentidos da democracia. Políticas do dissenso e hegemonia global. 2. ed. Petropólis, RJ: Vozes; Brasília: NEDIC, 2000.

PIRES, M.J.S.; RAMOS, P. O termo modernização conservadora: sua origem e utilização no Brasil. REN, v. 40, n. 3, p. 411-421, jul.-set. 2009. Disponível em: <https://ren. emnuvens.com.br/ren/article/view/367/315>. Acesso em: 10 fev. 2019.

ROSEMBERG, A. A questão social é um caso de polícia: da tragédia à farsa, uma ponte entre a Primeira República e o século XXI. Revista Hydra, v. 1, n. 2, p. 5-16, ago. 2016. Disponível em: https://periodicos.unifesp.br/index.php/hydra/article/view/9128/6661. 
SADER, E. (org.). 10 anos de governos pós-neoliberais no Brasil: Lula e Dilma. São Paulo: Boitempo; Rio de Janeiro: FLACSO, 2013.

SOUZA, J. A radiografia do golpe: entenda como e por que você foi enganado. Rio de Janeiro: LeYa, 2016. 144 p.

\section{Sobre o autor}

Luiz Fernandes Dourado é professor titular emérito da Universidade Federal de Goiás, doutor em Educaçáo pela Universidade Federal do Rio de Janeiro, com pós-doutorado em Sociologia na École des Hautes Études en Siences Sociales (EHESS), 2010. Diretor de Intercâmbio Institucional da Anpae.

Recebido em 28 de maio de 2019.

Aceito em 12 de setembro de 2019. 